\title{
The Roman Catholic Religion in Ireland and Cameroon: A Study of James Joyce's A Portrait of the Artist as a Young Man and Nkemngong Nkengasong's God Was African
}

Amungwa Veronica Nganshi

Adjunct Lecturer, English Department, University of Buea, Cameroon.

Amungwa Veronica Nganshi, E-mail: nganshi39@gmail.com

\section{ARTICLE INFORMATION}

Received: August 12, 2020

Accepted: September 30, 2020

Volume: 3

Issue: 9

DOI: 10.32996/ijllt.2020.3.9.17

\section{KEYWORDS}

Roman Catholic, religion, Ireland, Cameroon, colonised, postcolonial, autobiographical element

\section{ABSTRACT}

This paper explores how the Roman Catholic religion has influenced the writer in Ireland and Cameroon as projected in James Joyce's 1916 novel A Portrait of the Artist as a Young Man and Nkemngong Nkengasong's 2014 novel God Was African. The aim is to demonstrate that although Joyce is European and his work traces the development of a potential artist in a colonised Ireland and Nkengasong is African and projects the experiences of a scholar in a postcolonial Cameroon, both converge in the exploration and critique of the doctrine and teachings of the Roman Catholic Church whose mission is universal. Using the concepts of biography, history and culture of the New Historicist literary theory, this paper demonstrates that the critique of the Catholic Church is a projection of what Joyce and Nkengasong experienced in real life and thus they use their protagonists as mouthpiece to appreciate and at the same time condemn those practices they consider repressive with the aim of reformation. In other words, the authors project not what is dominantly fictional but what they were a part of. This autobiographical element makes their works closer to life. Though both authors believe literature should replace religion, their vision is that of a belief in God's existence, truth, sincerity and controlled individual freedom and for a society that upholds human dignity, mutual respect and morally upright conduct. The Roman Catholic Church has its flaws but its spiritual benefits are overwhelming as its doctrine is universal but operates within the realm of inculturation in respect of the positive values of the people's culture. This paper is therefore significant in bridging the dichotomy between art and life as the writer is projected as both subject and creator and the fact that religious values have a significant impact in the life of the writer. Thus, one of the ways to approach literature is from the autobiographical and religious perspectives.

\section{Introduction}

Religion plays a very vital role in the lives of a people. Writers of fiction usually are influenced by the beliefs and values of their society. The Roman Catholic religion is among one of the world's influential religions. Its doctrine and teachings are universal as its Christians all over the world live and practise the same values as enlightened by Scripture, Sacred Tradition and the Magisterium of the Church without discrimination (The Catechism of the Catholic Church, Compendium p.24) with the Pope in Rome as the visible head. This paper examines the role of the Roman Catholic Church in Ireland and Cameroon in James Joyce's 1916 novel A Portrait of the Artist as a Young Man and Nkemngong Nkengasong's 2014 novel God Was African respectively with the aim of illustrating that these authors' exploration and critique of the Catholic faith is prompted by their real life experiences. Although $A$ Portrait is a European and modernist text while God Was African is African and postmodernist, both converge on the themes of the Catholic notion of sin and punishment, the Sacraments of the Church (baptism, Confession, Holy Communion etc) and the conflict between religious values and the culture of the people. The experiences of the protagonists in the novels echo those of the authors. The outlook of Joyce and Nkengasong is greatly influenced by their Catholic upbringing. They thus write not about what is dominantly fictional but what they were a part of.

\footnotetext{
K C AL-KINDI CENTER R D FOR RESEARCH AND
} Your gateway to world-class research
Published by Al-KindiCenter for Research and Development. Copyright (c) the author(s). This is an open access article under CC BY license (https://creativecommons.org/licenses/by/4.0/) 
They use their protagonists as mouthpieces to project their views and feelings. There are bound to be differences as there are two writers from two different nationalities and continents. Nkengasong uses English, broken English and words and phrases including many proverbs that reflect the medium of communication of his Cameroonian society while Joyce uses English, baby language and so on to reflect the different stages of his protagonist's growth and his Irish background as well. The analysis focuses on the biographical, historical and cultural set up of Joyce and Nkengasong, a summary of their novels and the autobiographical parallels, the themes of sin and punishment, the sacraments and the conflict between Catholic religious values and the culture of the people.

\section{Literature Review}

Unlike Joyce's novel which has received so much critical appraisal, Nkengasong's God Was African has received a little although his earlier works have been highly exploited by critics. Mbangchia (2018), in a review on the novel identifies the following as motifs: cultural ecology, tradition versus Christianity, Western view of Africa, Africa's view of the West, mimicry, abrogation, appropriation, identity, hybridity, cultural consciousness and shock, and globalisation. In a structured interview with Nkengasong about his works, Teke (2013) quotes him as saying that:

the world is sick, very sick and I am of the opinion that it is Literature to heal it. I am also concerned about how African culture can be recreated or reinvented to change the world. Much of African culture was destroyed in the process of colonisation and imperial traditions imposed on Africans. Today such hegemonic traditions have lost their mettle and the world is turning towards Africa to reanimate the fading pulse of civilisation with something new, some rich and abundant cultural experience. So, I tend in my recent writing towards literary archaeology and artculturalism to retrieve positive lost values of Africa in art. This is my major preoccupation in my recent (unpublished) novel titled "God was African" (p.1).

This interview shows that Nkengasong wants to retrieve the positive lost values of Africa in his novel God Was African, and this includes traditional African religion. He continues in the same interview to say that a little truth or honest objectivity from politic men, religious leaders and the community as whole could heal the world, could make the world a better place. Unfortunately, religious institutions that were supposed to be the anointed preservers of truth have conspired against the very foundations of its institutions. And he thinks that if religion can no longer serve the purpose for which "God was created", literature would have to take its place. For him literature becomes a more effective way of expressing the verity of life and transcendental truths than religion can do (p.3). Nkengasong continues in the interview to say that in his works, he tries to bring Cameroon to the roots of its existence, those roots more than $70 \%$ of which were destroyed by colonisation and which neocolonial leaders have helped to eradicate by insistently preferring colonial models as is the case with Cameroon. Cameroon needs a cultural revival and it is his wish that his works can help retrieve some of the lost cultural heritage. Cultural nationalism can be buffered by what he described as art-culturalism. "My recent manuscript titled "God was African" experiments on the concept of art-culturalism" (10).

To understand Joyce properly - and especially his relation to the Church - we must, says Father Power (2016), understand Ireland at that particular moment in history. After the devastation of the Potato Famine, the country rebounded with a nationalist movement, which emphasized Catholic identity - but a kind of Catholicism that looked like Victorian Protestant respectability. Focusing on Joyce's influence with religion, Segall (1993) writes that Joyce, later in life, reconciled with the faith he rejected earlier in life and that his parting with the faith was succeeded by a not so obvious reunion, and that Ulysses and Finnegans Wake are essentially Catholic expressions (p. 120). Ellmann (1975) reports that there are different first- hand testimonies coming from Joyce, his brother Stanislaus Joyce and his wife about his attitude toward religion:

Six years ago I left the Catholic Church, hating it most fervently. I found it impossible for me to remain in it on account of the impulses of my nature. I made secret war upon it when I was a student and declined to accept the positions it offered me. By doing this I made myself a beggar but I retained my pride. Now I make open war upon it by what I write and say and do (p. 25- 26).

Welan (2002) opines that for Joyce's generation an Irish deep past no longer existed because it had been eviscerated by a dual colonialism $\neg$ British imperialism and Roman Catholicism (65). Welan states that in Dubliners and A Portrait of the Artist as a Young Man, "Joyce employs a repetitive lexicon to describe this colonized world-spectral, shriveled, stale, vague, mean, dull, dark, melancholy, somber...gloomy, listless. It is a world of shadows, condemned always to the second hand, to an identity based on alienation from self and others" (p.65). Focusing on the historical background of Joyce, Gibson (2007) states that the novel provides an account of what the recent history of Ireland was, its political and cultural hopes and prospects. Stephen's declaration in both A Portrait of the Artist as a Young Man and Ulysses that he will not serve is central to Joyce's 
work. His declaration in Ulysses that he must kill the priest and the king "in here" has the same crucial significance as his nonserviam in A Portrait of the Artist as a Young Man. His art is powered by a profound, intense and historically motivated concern with the assertion of independence (p.699). One concludes that the lives and works of Joyce and Nkengasong are influenced by religion, especially the Roman Catholic religion. The comparative study of the works is appropriate because both writers were born and raised as Roman Catholics. Ireland and Former British Southern Cameroon were colonized by Britain. Ireland had its independence in 1924 while Southern Cameroon had its own in 1961.

\section{Methodology}

The concepts of biography, history and culture of the New Historicist literary theory are used in the analysis of this paper since the life, historical and cultural circumstances in which Joyce and Nkengasong lived, greatly influenced their works. New Historicism evolved in the early 1980s with Stephen Greenblatt and Michel Foucault as the main proponents. New Historicism arose in opposition to New Criticism or formalism which dealt with a text in isolation from its historical context. New Historicists attend to the historical and cultural conditions of its production, its meanings, its effects and also its later critical interpretations and evaluations. (Abrams, 1999) explains that New Historicists conceive of a literary text as situated within the totality of the institutions, social practices and discourses that constitute the culture of a particular time and place, and with which the literary text interacts as both a product and a producer of cultural energies and codes (p. 182-183). Therefore, as Cox and Reynolds (1993) posit, New Historicism paves the way for interpretation of cultural texts and explores how historical forces such as social, economic, political, biographical, psychological, sexual and aesthetic phenomena interact with the cultural texts (p. 3). In this sense, New Historicism does not distinguish literary texts from non-literary texts, which is the most essential way of its reaction to formalist criticism.

As a theoretical concept, New Historicism views literature as part of history, and furthermore, as an expression of forces on history. New Historicism compares literary analysis to a dynamic circle whereby the work tells us something about the surrounding ideology (slavery, rights of women, etc.) and a study of the ideology tells us something about the work. Generally, New Historicism takes two forms, namely: analysis of the work in the context in which it is created and analysis of the work in the context in which it is critically evaluated. The key assumptions of New Historicism are embedded in its understanding of several related concepts: culture, text, discourse, ideology, the self and history. These concepts, in turn, establish the New Historicist approach to the study of literature and are based on structuralist and post-structuralist theories of language. The first term, culture, is the most important. In an anthropological sense, "culture" is the total way of life of a particular society-its language, economy, art, religion, and attachment to a location. For New Historicists, culture is also a collection of codes that everyone in a society shares and which allows them to communicate, create artifacts, and act. These codes include not just language but every element of a culture-literature, dress, food, rituals, and games.

\section{Discussion}

\section{Biography of Joyce and Nkengasong Joyce's Upbringing}

A New Historicist approach in the analysis of this paper necessitates an account of the life, historical and cultural set up of James Joyce and Nkemngong Nkengasong since their works reflect their views of the Roman Catholic religion in which they grew up as well as its influence on their respective societies. Ellmann (1983) writes that James Augustine Aloysius Joyce was born on 2 February 1882 to John Stanislaus Joyce and Mary Jane Murray in the Dublin suburb of Rathgar. He was the eldest in a family of four boys and six girls. Joyce's father, John Joyce had inherited property in his home town, Cork and was Collector of Rates for Dublin at the time of James's birth. It was an undemanding, well-paid post, but John Joyce was a reckless spender and a heavy drinker, and he had begun to mortgage his Cork properties as early as 1881 . As his family grew in number, so did the mortgages (eleven altogether). In 1892, his post was abolished and he was pensioned off at the age of forty-two. Thereafter, a rapid decline in the family fortunes set in. James had been sent to Clongowes Wood College, a highly thought of Jesuit school in county Kildare, but was withdrawn in 1891 after three years there. He spent some time at a Christian Brother's School until Father Conmee, former rector of Clongowes who knew him as a very promising pupil, kindly arranged for him to have a free place at Belvedere College, the Jesuit School in Dublin.

Just now John Joyce, walking in Mountjoy Square one day, had a fortunate encounter with Father John Conmee, who had left the position of rector of Clongowes to become prefect of studies at Belvedere College... Hearing that his former pupil was obliged to attend the Christian Brothers' school, and remembering his ability, Conmee kindly offered to arrange for James, and his brothers too, to attend the fine Jesuit day-school, Belvedere College, without fees ( $p$. 35). 
Joyce will echo this life experience in A Portrait of the Artist as a Young Man by narrating how Stephen's father (John Joyce) arranges with Father Conmee for his admision into Belvedere College. "One evening his father came home full of news which kept his tongue busy all through dinner...Don't I tell you he's provincial of the order now? - I never liked the idea of sending him to the Christian brothers myself" (p.65-66). Joyce uses the real name of the priest and school in his novel to show how he was touched by this kind gesture. At first Joyce worked well at Belvedere: he won exhibitions in annual examinations and was noted for his piety, becoming head of the Sodality of the Blessed Virgin Mary in 1869. However, it appears that in that same year, at the age of fourteen, he met a prostitute one night and had his first sexual experience. Not long afterwards, in a school retreat conducted by Father James A. Cullen at the end of November and at the beginning of December 1896, Joyce was deeply stirred by guilt feelings, went to confession, and for some months tried seriously to live a life of piety (48- 49). But his faith then began to disintegrate. He rejected the suggestion to become a priest and became more careless in his studies.

Joyce went to University College, Dublin, in 1898, where he studied English, French and Italian, and took his B.A Degree in 1902. Throughout his Belvedere and his university days the home situation was deteriorating. John Joyce was drinking and boasting the family into poverty. He moved the family from house to house to escape the landlords, having sometimes burnt the house banisters for firewood. He was cruel to his wife and once when drunk tried to strangle her (Ellmann p.136). He wrote movingly about the family's collapse in A Portrait of the Artist as a Young Man, where the children discuss an impending eviction in a private nonsense language: "Because-boro theboro landboro lordboro willboro putboro usboro outboro."(p.149)

As concerns Joyce and religion, Segall (1993) writes that Joyce, later in life, reconciled with the faith he rejected earlier in life and that his parting with the faith was succeeded by a not so obvious reunion, and that Ulysses and Finnegans Wake are essentially Catholic expressions (p.120). Likewise, Hugh Kenner and T.S. Eliot saw between the lines of Joyce's work the outlook of a serious Christian and that beneath the veneer of the work lies a remnant of Catholic belief and attitude (Segall p.142). Somewhat cryptically, in an interview after completing Ulysses, in response to the question "When did you leave the Catholic Church", Joyce answered, "That's for the Church to say." We have different first- hand testimonies coming from Joyce, his brother Stanislaus Joyce and his wife about his attitude toward religion as repoted by Ellmann:

My mind rejects the whole present social order and Christianity -home, the recognised virtues, classes of life, and religious doctrines. [...] Six years ago I left the Catholic Church, hating it most fervently. I found it impossible for me to remain in it on account of the impulses of my nature. I made secret war upon it when I was a student and declined to accept the positions it offered me. By doing this I made myself a beggar but I retained my pride. Now I make open war upon it by what I write and say and do (p. 25-26).

Joyce reflects his hostility to religion in his novel when Stephen replies to Cranly's question if he intended to become prostestant by saying that "I said that I had lost the faith, Stephen said, but not that I had lost self- respect" (p. 220).

From this view it is clear that Joyce was a man of conviction who hated hypocrisy and "believed in individual freedom". Individual freedom does not however mean indulging in one's whims and caprices. That is why Burke (2007) explains that the presence and operation of human freedom means that there is no such thing as automatic fulfillment for anyone. Man is free but not autonomous. He is free but not independent. His own capacities limit him physically and psychically (p.18-19) Joyce echoes his conviction in A Portrait of the Artist as a Young Man by writing that "I will no longer serve that in which I no longer believe whether it call itself my home, my fatherland or my church" (p.222). He goes on to declare that "I am not afraid to make a mistake, even a great mistake, a lifelong mistake" (p.223). He is therefore determined to bear the consequences of rejecting his religion, family and country because he is convinced he is doing so for a good cause. Eric Bulson, in The Cambridge Introduction to James Joyce, writes that when asked by a catholic priest if she wanted a religious service, Nora refused; "I couldn't do that to him." A wreath with a lyre symbolizing Ireland was placed by the graveside. Having rejected his catholic faith, Nora thought she was doing Joyce a favour. But that catholic faith had al ready shaped Joyce.

\section{Nkengasong's Upbringing}

Nkemngong Nkengasong was born John Ngosong Nkemngong Nkengasong in 1959 in the village of Lewoh in Lebialem Division of the semi-Bantu ethnic group called Bangwa in the South West Region of Cameroon. He attended primary school in Lewoh in Lebialem and Mamfe, then he later attended Seat of Wisdom College, Fontem and the University of Yaounde 1 where he obtained a Bachelor's degree, Master's degree and a PhD in English literary studies. He is a Cameroonian playwright, novelist, poet and scholar. He is often referred to as a "radical visionary" of Anglophone Cameroon ( Varuguese $p$. 62) and an "ardent upholder of innovative creativity and crusader for the truth" ( Teke p.1) as is demonstrated by his novels, poetry, short stories and plays. Nkengasong spent part of his early childhood in his native Lewoh, a polity within the larger 
Nweh tribe of the Lebialem Division of the Southwest Region of Cameroon. The countryside's craggy and verdant scenery and its splendid culture are richly represented in his writing (Labang p.146). In 1971 he completed primary school and enrolled in Our Lady Seat of Wisdom College Fontem (Ambanasom p. 208). At that formative age, he became conscious of the centrality of literary creativity in human experience and he began writing poems some of which were published in the college magazine.

After graduating from High School, he read English at the then University of Yaounde, specializing in English Literature while taking elective courses in Theatre Arts. Between 1979 and 1982, the years of his undergraduate studies, he wrote poems some of which were published in The Mould, a journal of creative writing founded by Bole Butake and in The New Horizons, another journal of creative and critical writing founded by Tala Kashim Ibrahim. With a Bachelor of Arts degree in English obtained in 1982, he registered in the second cycle of the Higher Teacher Training College, University of Yaounde, graduating in 1984 as a High School teacher. While he taught in High School, he pursued graduate studies, earning a "Maitrise" in 1985 and in 1993, a "Doctorat de Troisième Cycle" degree from the University of Yaounde. He was recruited as an Assistant Lecturer at the University of Yaounde 1 in 2000, and in 2004 he obtained a PhD in English Literary Studies (Teke p. 11). The University offered him fertile grounds to explore his burgeoning creative talents, leading to the publication of several plays, prose works, poetry and essays which have sought for him national as well as international acclaim. He is currently Professor of Literature and Cultural Studies in the University of Yaounde 1, the chair of the department of Curriculum and Evaluation, in the same University and the Dean of the Faculty of Arts, University of Buea in the South West Region of Cameroon.

Apart from his creative works, he has published extensively on African Literature and Culture, British and Postcolonial Literatures and Cameroonian Pidgin. Besides teaching and research, he is a creative writer who has published fictional works including God Was African, Across the Mongolo, The widow's Might, Achakasara and several short stories; plays including Black Caps and Red Feathers, the Call of Blood, Ancestral Earth, A madding Generation, Njogobi Festival; and a collection of poems titled Letters to Marion and the Coming generations. He is the former president of the Anglophone Cameroon Writers' Association (ACWA) and the Vice President of the Union of Cameroonian Writers. On the international scene he has been a Fulbright scholar at New York University, guest author in Corpus Christi College, University of Oxford, participant at the International Writing Program, University of Iowa, USA, a panelist in the Chicago Humanities Festival, guest speaker in the National University of Singapore, amongst others.

\section{Historical/ Cultural Background to A Portrait of the Artist as a Young Man and God Was African Joyce and the Irish Experience}

Joyce was greatly influenced by the historical and cultural background against which he wrote. The Act of Union which made Ireland part of the United Kingdom and abolished the separate Irish Parliament was abolished in 1800. Throughout the nineteenth century various movements developed which gave expression to the demands of the Irish for greater control of their own affairs at home. British rule had given to Ireland not only an Anglo-Irish aristocracy of landowners but also a Protestant Church of Ireland of which the ruling minority tended to be members. Thus, the Roman Catholic Church was largely the church of the peasantry and the majority of the Irish population. In the last decades of the nineteenth century there was a very complex relationship between the numerous movements in which the desire for a distinctive Irish identity expressed itself (Blamires p. 7).

There were movements for land reform which were designed to improve the lot of the Irish peasantry, movements for Home Rule in an Irish parliament, movements for total independence from Great Britain and the setting up of a republic, movements to revive Gaelic as the national language, and movements to revitalise Irish literature in English from historic and legendary Irish sources. An Irishman might be a keen advocate of one or more of these causes and yet be at loggerheads with a fellow-Irishman who supported another of these causes. The possibilities for argument and strife among the Irish themselves were vast. Charles Steward Parnell (1846-91) was the great advocate for parliamentary Home Rule for Ireland. Michael Davitt (1846-1906) was an advocate for land reform. The attempts of the British Prime Minister, W. E. Gladstone (1809-98), to establish Home Rule in Ireland were defeated at Westminster in 1886 and 1892 during Joyce's childhood and youth (Blamires p. 7).

The story of Parnell's downfall casts a shadow over A Portrait of the Artist as a Young Man. It illustrates how complicated was the relationship between different factions of nationalistic Irishmen. Parnell's work in the Land League for securing landownership for tenant farmers and his leadership of the Home Rule Party as a Member of Parliament at Westminster gained him immense popularity at home and the title of uncrowned King of Ireland. When in 1890, he was cited as correspondent in a case by Captain William O'Shea on the grounds of adultery with his wife, most of his party deserted him and the Catholic clergy turned against him. He died soon after in 1891, and intense bitterness was felt by those of his supporters who had 
remained loyal to him. They regarded him as a hero who had been treacherously betrayed and their anger was acute and long-lasting. The grip of the Roman Catholic Church on the mass of the Irish was a powerful one. The Catholic Church's moral condemnation of Parnell was typical of what often happened at crucial turning-points in Irish political history. Loyalties were confused. Joyce was brought up in a Catholic family with a pious mother and a father who was an enthusiastic Home Ruler and supporter of Parnell. John Joyce's anti-clericalism was not shared by his wife nor by "Dante" Conway, a woman who was brought into the Joyce household to be a governess ("Dante" was a childish corruption of "Aunty"). She was a fierce supporter of the clergy. Dante's influence on the child James is made evident in A Portrait of the Artist as a Young Man (Blamires, p. 8).

Joyce's education was well looked after by the Jesuits and it was logical that he should go to the University College which was founded in 1852. It was a Catholic University. Joyce's short stories, Dubliners, present the people of Dublin as given to talk, sentimentality and acquiescence rather than to decisive action. Yet at the turn of the century Dublin was astir with new ideas and enthusiasm in the cultural field. There was a revival of interest in the Gaelic language and this was also to give Irish literature in English a native vitality that would be the mainspring of the campaign for political independence. At the same time enthusiasts were working for the establishment of an Irish National Theatre in Dublin. A Portrait of the Artist as a Young Man refers to the first performance of W. B. Yeats's (1865-1939) play, the first venture of what was called the Irish Literary Theatre. Joyce himself was present on this occasion and sympathised with Yeats when the play provoked a clash with upholders of catholic orthodoxy. In 1904, the year Joyce left Dublin for good, the first performances were given in the Abbey Theatre by Yeats and Lady Augusta Gregory (1852-1932). Other names associated with the Irish literary movement at this time were George Moore (1852-1933), the novelist, and John Millington Synge (1871-1909), the dramatist (8).

Joyce's inability to share the enthusiasms of these various writers, like his detachment from the movement to popularise the Irish language, was partly due to his rejection of Irish cultural narrow-mindedness. His early enthusiasm for the Norwegian dramatist Henrik Ibsen (1828-1906) shows how European his interests were. His grounding in English literature made him scornful of people who tried to push the Gaelic language by denigrating English. His sense of the wastefulness of violence made the mentality of the extreme nationalists repellent to him (p.9). These were some of the complex reasons behind the dissatisfaction with Ireland which led Joyce to exile. There were more personal motives too. The young James Joyce had his share of vanity and pride. Consequently, Joyce felt he had a claim on the support and patronage of established writers which he did not always receive. He could be prickly, even uncouth, when he thought he was being patronised or not given his due.

His poverty did not help to make him a socially presentable figure and some of his personal habits did not help him either. He was helped in various ways by Lady Gregory, Yeats and George Russell (1867-1938). In spite of this, leaving Ireland seemed essential to a young man who wished to dedicate himself to writing and whose family situation was such that not even the most strenuous labour nor the most saintly patience and sympathy, could rescue the home from squalor and disorder. John Joyce had once screamed drunkenly at his dying wife, "Die and be damned to you". The great irony of Joyce's literary achievements is that the man who left Ireland with the conscious determination to work in exile never wrote anything that did not focus lovingly as well as critically on Dublin and its inhabitants (Blamires, p.9).

Although Joyce later rejected Catholicism, he admired Catholic intellectuals like Cardinal Newman. His choice of religious terms to describe aesthetic phenomena such as "epiphany, epiclesis, eucharistic moment" as Thornton points out (p.195), show how he was influenced by his Catholic religion. This influence is recorded by Stanislaus Joyce (1958) to whom Joyce said "Don't you think ... there is a certain resemblance between the mystery of the Mass and what I am trying to do? I mean that I am trying in my poems to give people some kind of intellectual pleasure or enjoyment by converting the bread of everyday life into something that has a permanent artistic life of its own ... for their mental, moral, and spiritual uplift..." (p. 103-104). The same analogy is expressed by Stephen in A Portrait of the Artist as a Young Man when he thinks of himself as "priest of eternal imagination, transmuting the daily bread of experience into the radiant body of everlasting life" (p. 200).

\section{Nkengasong and the Cameroon Experience}

Cameroon is a country in central Africa. It is a bilingual country whose official languages are English and French. Cameroon was formerly two countries with the East colonised by France and the West, known as former British Southern Cameroon, by Britain. The country now is a unitary state with the former British colony which is English speaking occupying the North West and South West Regions while the rest of the country is French speaking. Nkengasong comes from the English speaking part in the South West Region. Given that religion is inextricably linked to culture, especially in the African context, any attempt at studying African peoples and cultures that does not involve a meticulous examination of traditional African religions would be incomplete (Ndemanou p.71). Traditional religions have had tremendous influence on Africans in their thought processes, belief systems, and worldviews. Traditional African religions do not have a sacred text with prescribed doctrines as does 
Christianity with the bible and other spiritual books. Cameroon happens to be one of the African countries in which traditional religions remain firmly engrained in its people's thinking and ways of life. Cameroon is a secular state that is blessed with over 250 ethnicities and 250 languages (Ethnologue, 2016), and many religious groups including Christianity, Islam, and traditional African religions.

There is a fallacious conventional wisdom that holds that Africa did not know God prior to its Arab incursion and European colonialism (Njoh \& Akiwumi, 2012). It is believed that traditional African religions have been around since the beginning of humanity. Although there are varieties of traditional African religions, they share more similarities than differences in their practices (Stinton, 2004). One observable commonality is that most of them do not have a written Holy text for references. Therefore, it is difficult for any Westerner and non-African to have an in-depth knowledge about them because their beliefs and practices have not been canonized as was the case with the Bible when the Council of Nicaea met under the auspices of the Roman Emperor Constantine I to initiate the writing of the Scriptures. Njoh and Akiwumi (2012) argue that one major feature of traditional African religion is that religion is a way of life for Africans. Africans' modi operandi are inextricably intertwined with their religions. The only slight distinction one can notice is between the more religious and the less religious individuals in terms of the frequency of their visits to the shrines and temples, or lack thereof, to consult with the diviners, perform rituals, or transmit messages to the ancestors. Mbiti (1970) states that African religion starts before birth and does not end after death. Whether Africans are part of the modern organized religion today or not, they invoke God in their everyday conversations.

It is worth noting that Cameroonians ferociously resisted foreign religions in the $18^{\text {th }}$ century to maintain their traditional religions when Christianity entered Cameroon (Betoto, 2012). The Catholics, like other denominations, figured out ways to coerce many Africans to convert to Christianity without directly attacking their traditional religious values. Cameroonians were adamantly opposed to Christian groups that were hostile to their traditional religions. Until lately, the Pentecostal churches found it very difficult to attract adherents because they advocated the destruction of traditional religious symbols. The Catholics chose to tread a fine line by embracing some of the African cultural and religious practices that did not markedly deviate from their Western church's own canons. This explains why the celebration of mass in many parts of Africa is slightly different from the way it is practised in Europe or in North America. There is a glaring adoption of African religious and cultural practices in the Catholic churches in Cameroon generally without which many Cameroonians might have been deterred from joining the church. For example, in Lebialem where Nkengasong grew up, traditional African religion influenced some of the rituals that occurred in church.

Some of the African-derived practices in some Western churches in Africa include: harvest thanksgiving, tithing in cash and in kind, choral music, twin-dance procession with a green leafy peace tree whose stems are often cut off and used as a symbol of peace during a church choir. There is a cultural and religious symbolism of this peace tree known in Nweh (a language spoken by the Bangwa) as " $n k e n g$ " (Ndemanou p. 78). Using it in a church choral procession and in decorating the altar makes the church more appealing to skeptics of European Christianity. The in-kind tithing with kola nuts, fruits, and other edible items instead of money is reminiscent of the African traditional religion in which an elder takes the best harvest to the shrine to make sacrifices to God. Meanwhile the food brought in place of cash for tithe is either auctioned after the celebration of mass or given to the needy. Christians of Western churches who have tried to dissociate themselves from traditional African religion are still heavily influenced by the belief systems because it is extremely difficult to separate religion from culture. Talking about the attitude to the death of a Christian who also upholds his traditional religious belief, Bishop Andrew Nkea (Chiara,2016) states:

The whole notion of remembering their dead is one aspect that is embedded in the Bangwa culture and beliefs. This is known as "cry die". Cry die is a good and noble practice of remembering our dead, after all the church has dedicated the whole month of November to the memory of the dead and Christians are encouraged to go and pray in cemeteries. The typical Bangwa man feels the obligation to organize cry die for his dead relatives and this is good. Bishop Nkea Andrew in an interview cautioned that:

But we must baptise this practice with our motivation for the celebration of cry die. For the Christian, we remember our dead and we pray for them to be released from their sins and brought to heaven. We celebrate the lives of these departed relatives in thanksgiving to God for who they were to us and the legacy they left behind. There should be in a Christian a departure from the non-Christian belief that we must organize cry die for our departed relatives, otherwise we shall have misfortunes. This is superstitious. This is why Christians are encouraged at all times to begin their cry die with the Holy Mass which is the sacrifice of the memorial of the passion and death of our Lord Jesus Christ (Chiara, 2016 www.focolare.org). 


\section{Summary of A Portrait of the Artist as a Young Man, God Was African and their autobiographical parallels}

It is noteworthy that the protagonists of the two novels both have names with Christian undertones or allusion which reveal the influence of Christianity on the two writers. Kendem is a corruption of Nkue- ndem which means God's message while Stephen is the name of the first Christian Martyr. God Was African is a 2014 novel of thirty- one chapters which narrates the struggles of Kendem, its protagonist, within the limits of human consciousness. After being fade up with excesses of civilization in America, Kendem, the protagonist, decides to return to his native Anya village in Lewoh where he can find some relief in the calm and serenity of the village. When he arrives at the village square, at his mother's palm wine bar (the lasting one in the village), his sick mother, who has been waiting for him, welcomes him with the question "Did you see your brother?" He is unable to answer this question because he does not know how to start narrating the "story" of his brother. Another burning issue at hand, in the village, is the dispute over Fuo Beyano's funeral: whether the deceased village chief should be given a Christian burial or he should, according to the age-old tradition of Lewoh people, go through a ritual to enable him to return and continue ruling his people in the guise of his successor. When everyone leaves the bar, his mother repeats the question concerning his brother "Child, did you see your brother in Ameleka? A number of people come to greet him: Nkembeteh, Nkembefok, Nkemlegangambong and Anumbondem, alias Bombabili. In a heated argument amongst the visitors, Bombabili says "I am a proud Lewoh man. When you people talk the beautiful place you have go to, I talk the beautiful place I was born to. I was born in Lewoh, I have travel in Lewoh. Lewoh is the capital city" Here, the protagonist thinks Bombabili is directly referring to him and he feels guilty. This results from his long absence from his cultural roots and his persistent pursuit of "books" and not "native knowledge". At night on the same day, the protagonist's mind is filled with the journey he made to the USA and the efforts he made to find his brother: he won a Fulbright scholarship to take part in an international programme in America, a programme attended by seventeen scholars from all over the, world. As the group attend different conferences, Kendem discovers that there is extreme racism in America.

He is looked upon as an inferior human being by other pilgrims in the group, especially one of them called Lebanajar. When questioned by Lebanajar on whether Cameroon, Kendem's country, has roads, Kendem says "No". He insists, mockingly, that in Africa they live on trees. At the New York University, McDough, a professor of Economics, delivers a speech on the topic "Poverty in America: Individualism and American Business Enterprise" While discussing, Prof. Mcdough dwells on poverty in the African continent. He says "Africa is very poor," "Only a few people can afford to eat one good meal a day," as a result of this, Kendem thinks of the untold hazards that Africa has suffered and is suffering in the hands of the western world. The story digresses to the present where Kendem's mother urges him to go and condole with orphans and widows of the late Fuo Beyano. He plans his journey with Bombabili. The latter gives him information about the matter in Beyano village as "Dockta, you know what?" "I almost forget to tell you. The people of Beyano village have decided to revamp the late chief in a traditional way. There is a big trouble in the village right now." They go through valleys and hills and Bombabili gives a brief history of the spirits that inhabit the zones. Immediately as they arrive, they are surprised because there is a heated argument on the burial of the late Fuo Beyano. The next day, Kendem visits Anya palace to great the young prince. There, he meets them in the Mbelekong where the chief is presiding at the Lefem meeting.

The removal of Fuo Beyano's corpse from the Africa Mission Hospital is scheduled for Alena, the day after the Lewoh Market day. That night Kendem sleeps as he had never done before. In the morning, in a stream of consciousness, the issue of his brother takes him back to his stay in America. In America, Kendem is surprised to hear of Gay Parade that is to take place on Sunday. On Sunday at the 23rd Street on the Fifth Avenue the crowd gathers to watch the parade. Men and men, women and women marched with banners to celebrate their gayism. He goes through the World Trade Centre to see if he can see traces of his brother, whom he had not seen for almost a year of living in America. In the streets, the images of the famous September 11 incident fill his mind and he immediately remembers his childhood days, when his father's Lemoo caught fire and how the community came to put it out and to rebuild the house for his family. Here, he laments the excessive malaise of the Western Word. Kendem's cousin calls him to give him information about his brother. He has lost his identity in America. When he toils for days in search of his brother, he finally enters a restaurant and sees a black guy shoving a saucepan, forward and backward. He marvels at the speed with which the fellow does the activity, looks at the performer's face and discovers that his brother is the one. His brother obtains permission from his boss and takes Kendem to the other side of the restaurant. Through their discussion, Kendem discovers that his brother is a dead man alive, a prisoner in a different world, yet feeling very proud of it. His brother, Tonny, had been jailed for some time and he speaks with so much ease about his troubles in America, yet still wants to live there. He even persuades Kendem to stay in America after his programme. He 
declines showing Kendem where he lives and directly retreats to his duty, saying that he has shifts. However, he promises Kendem to take him to his house on Wednesday.

On Wednesday, he fails his appointment and on Sunday he takes Kendem to a shabby area where he sleeps with other niggers. This meeting makes Kendem's vision about civilization in the Western World blurred. This is the last week Kendem has in the US. At the end of the programme, Kendem travels with Tugu and Tuniz-Aziz back to Africa. At the end of that long journey in Kendem's mind, he wakes up and is prepared to go for the burial of Fuo Beyano. He meets the others in church for the funeral mass and later leaves with Bombabili to the palace for the traditional phase of the burial. There, he is accepted to be part of the burial ritual because he is a scholar. There is unity among the villagers. As the procession is going on, they sing in unison. That night Kendem's mind floats from the present to the past.In the morning, his mother comes in to his room, asking after his brother. Kendem gathers courage and tells her that he saw his brother and his brother sent greetings with the promise of later sending gifts. He says "Mami he is not ill but he is not well." (p.288). His mother is dumbfounded after hearing this. Immediately, Bombabili enters and says the enthronement of the new chief was good. As the story ends, Kendem's imagination goes from his brother to the seventeen pilgrims to the repose of his ancestors, while sitting with his mother looking towards the ancestral shrine.

There is an autobiographical parallel between Kendem the protagonist and Nkemngong Nkengasong. Both Kendem and Nkengasong are natives of Lewoh in Lebialem Division of the South West Region of Cameroon. Kendem attended the same schools like Nkengasong: primary school in Lewoh in Lebialem, then Seat of Wisdom College, Fontem and the University of Yaounde 1. Kendem mentions himself as a student of Seat of Wisdom in God Was African: "When later I was a student in Seat of Wisdom College I reached the pinnacle of my faith as an altar boy by participating in the ordination of three priests..." (p.29). Nkengasong is a Fulbright scholar and so is Kendem as seen in God Was African: "...you have been finally selected by Washington to participate in the Fulbright Institute of American Civilisation" (p. 48). Kendem is a university lecturer at the University of Yaounde just like Nkengasong: "I crossed...to my office in the Department of English at the University of Yaounde where I worked as an instructor" (p. 48). The blend of traditional and Catholic religious practices in the novel is reminescent of the real life practices in the Bangwa culture of Nkengasong. Ndemanou (2018) posits that:

There is a glaring adoption of African religious and cultural practices in the Catholic churches in Cameroon generally without which many Cameroonians might have been deterred from joining the church. For example, in the Bangwa land, traditional African religion influenced some of the rituals that occurred in church. Some of the African-derived practices in some Western churches in Africa include: harvest thanksgiving, tithing in cash and in kind, choral music, twin-dance procession with a green leafy peace tree whose stems are often cut off and used as a symbol of peace during a church choir. There is a cultural and religious symbolism of this peace tree known in Nweh (a language spoken by the Bangwa) as "nkeng". Using it in a church choral procession and in decorating the altar makes the church more appealing to skeptics of European Christianity (p.4).

In God Was African, Kendem reports the offertory procession of the requiem mass of the late Chief as a blend of both Catholic and traditional rites of the Lewoh people which reflects Ndemanou's account: "The offertory procession was led by a small group of communicants who carried a special gift... they were dressed in traditional outfit and danced to the vibrant rhythm of eseih, singing and waving $n k e n g$ leaves in and out... the other communicants carried personal precious gifts of sacrifices including fruits, eggs, plantains, cocoyams, envelops, bank notes and coins to offer to the Maker" (p. 274- 275).

Joyce's A Portrait of the Artist as a Young Man tells the story of Stephen Dedalus, a boy growing up in Ireland at the end of the nineteenth century, as he gradually decides to cast off all his social, familial, and religious constraints to live a life devoted to the art of writing. As a young boy, Stephen's Catholic faith and Irish nationality heavily influence him. He attends a strict religious boarding school called Clongowes Wood College. At first, Stephen is lonely and homesick at the school, but as time passes he finds his place among the other boys. He enjoys his visits home, even though family tensions run high after the death of the Irish political leader Charles Stewart Parnell. This sensitive subject becomes the topic of a furious, politically charged argument over the family's Christmas dinner. Stephen's father, Simon, is inept with money, and the family sinks deeper and deeper into debt. After a summer spent in the company of his Uncle Charles, Stephen learns that the family cannot afford to send him back to Clongowes, and that they will instead move to Dublin. Stephen starts attending a prestigious day school called Belvedere, where he grows to excel as a writer and as an actor in the student theater. His first sexual experience, with a young Dublin prostitute, unleashes a storm of guilt and shame in Stephen, as he tries to reconcile his physical desires with the Catholic morality of his surroundings. For a while, he ignores his religious upbringing, throwing himself with debauched abandon into a variety of sins-masturbation, gluttony, and more visits to prostitutes, among others. 
Then, on a three-day religious retreat, Stephen hears a trio of fiery sermons about sin, judgment, and hell. Deeply shaken, the young man resolves to rededicate himself to a life of Christian piety.

Stephen begins attending Mass every day, becoming a model of Catholic piety, abstinence, and self-denial. His religious devotion is so pronounced that the director of his school asks him to consider entering the priesthood. After briefly considering the offer, Stephen realizes that the austerity of the priestly life is utterly incompatible with his love for sensual beauty. That day, Stephen learns from his sister that the family will be moving, once again for financial reasons. Anxiously awaiting news about his acceptance to the university, Stephen goes for a walk on the beach, where he observes a young girl wading in the tide. He is struck by her beauty, and realizes, in a moment of epiphany, that the love and desire of beauty should not be a source of shame. Stephen resolves to live his life to the fullest, and vows not to be constrained by the boundaries of his family, his nation, and his religion. Stephen moves on to the university, where he develops a number of strong friendships, and is especially close with a young man named Cranly. In a series of conversations with his companions, Stephen works to formulate his theories about art. While he is dependent on his friends as listeners, he is also determined to create an independent existence, liberated from the expectations of friends and family. He becomes more and more determined to free himself from all limiting pressures, and eventually decides to leave Ireland to escape them. Like his namesake, the mythical Daedalus, Stephen hopes to build himself wings on which he can fly above all obstacles and achieve a life as an artist.

A Portrait of the Artist as a Young Man details events which closely correspond with those of Joyce's first twenty years. According to Joyce's celebrated biographer, Richard Ellmann, Joyce hoped that his Portrait would be an autobiographical novel, "turning his life into fiction." While scholars disagree on the extent to which Joyce's life affected his fictional narrative in the novel, most of them concur that Stephen Dedalus is both the protagonist of the novel, as well as the persona behind which Joyce paints his fictional "portrait" of the "artist" and of the "young man." Although several themes such as alienation and betrayal exist in the novel, Ellman states that Joyce originally recognized the work's main theme as "the portrait of the renegade Catholic artist as hero." Certainly, evidence from Joyce's life mirrors Stephen's need to escape the bonds of Irish nationalism and Catholicism, both of which seemed to threaten his pursuit of a literary career (cliffnotes on a portrait).

Just as there is a parallel between Nkengasong and his protagonist Kendem, there is also a parallel between Joyce and Stephen Dedalus, his protagonist in A Portrait of the Artist as a Young Man. The schools and other institutions which Joyce attended or visited in real life are the same Stephen attends in the novel. Joyce and Stephen have much in common. Both were indelibly marked by their upbringing in Catholic Dublin, a city that harboured the dreams of being the capital of an independent nation which in reality was ruled by England. Like Stephen, Joyce was the eldest son of a family of ten children that slid rapidly down the social and economic ladder. When Joyce was born in 1882, the family was still comfortably off. But its income dwindled fast after Joyce's sociable, witty, hard-drinking father, John Stanislaus, lost his political job as Stephen's father, Simon, loses his - after the fall of the Irish leader and promoter of independence, Charles Stewart Parnell. Although the loss of the post was not directly related to Parnell's fall, Joyce's father worshipped "the uncrowned king of Ireland" and blamed his loss on anti-Parnell forces like the Roman Catholic Church. Joyce portrays the kind of strong emotions Parnell stirred up in the Christmas dinner scene in Chapter One of $A$ Portrait of the Artist as a Young Man. Like Simon Dedalus, the jobless John Stanislaus Joyce was forced to move his family frequently, often leaving rent bills unpaid.

Some of the characters who influenced Joyce's life and consequently his writings are John Kelly, who appears in A Portrait of the Artist as a Young Man under the name of John Casey and Dante Riordan. According to Richard Ellmann (1972), Kelly was in prison several times for Land League agitation, and John Joyce regularly invited him to recuperate from imprisonment, at that time very rigorous, at the house in Bray (p.24). Kelly was frequently in danger of being rearrested. Once a constable named Joyce, who was friendly with John Joyce because of their name, came to the house late in the evening to warn them that he would have to serve a warrant on Kelly in the morning. Kelly escaped by car that night. Consorting with an enemy of the crown was probably risky enough for an officeholder, but John Joyce never equivocated about his nationalism, and his growing and outspoken devotion to Parnell, which Kelly fully shared, was already forming the mind of his watchful son James Joyce who portrays this in the quarrel at the Christmas party (p.24). Soon after the Joyces moved to Bray, they were joined by Mrs. 'Dante' Hearn Conway from Cork, who was to act as governess to the children: "A fat, clever woman, she was too embittered by a disastrous marriage to fit easily into the tolerant, high-spirited household" (p.24).

She had been on the verge of becoming a nun in America when her brother, who had made a fortune out of trading with African natives, died and left her 30,000 pounds. She came back to Ireland to settle her inheritance and instead of returning to the United States, gave up the convent and settled in Dublin to find a husband. She allowed herself to be won by an overdressed employee of the pillared Bank of Ireland. Soon after their marriage, Conway ran off to South America with her 
money, and quickly ceased to write her promises to return. For the rest of her life Dante Conway remained the abandoned bride, and her burning memories of being deserted joined remorse at having left the convent to make her overzealous, in both religion and nationalism. She presided at the recitation of the Rosary and the Litany of the Blessed Virgin Mary, and she had, as James Joyce wrote, two brushes, one painted in maroon for Davitt and his Land League, the other in green for Parnell. Her loyalties clashed bitterly when Parnell was found to have been an adulterer, but it is not hard to see why she should have at once abandoned this betrayer of marriage ties and torn off the green backing from her second brush (p. 24-25).

Another influential, though a minor character, is Eileen Vance. By age and temperament Joyce became the ringleader in the children's games. Along the street, at 4 Martello Terrace (not 7, as A Portrait of the Artist as a Young Man says), lived a chemist named James Vance with his family, and although the Vances were Protestant, the families were quickly drawn together. Vance's bass voice boomed against John Joyce's light tenor in 'Come-all-ye's.' The Vances' eldest child, four months younger than James, was a pretty girl named Eileen, and the two fathers often spoke half-seriously of uniting their first-born. Dante Conway warned James that if he played with Eileen he would certainly go to hell, and he duly informed Eileen of his destination but did not cease to merit it. Hell and its superintendent had already become useful histrionic counters for him (Ellmann 26). This shows how fanatical Dante was in terms of religious beliefs. This incident contributed, in later life, to Joyce,s rejection of religion.

Another real life character, whose behaviour affected Joyce negatively and subsequently influenced his dislike of the Catholic faith, is Father James Daly. He is involved in an event which is described in A Portrait of the Artist as a Young Man and confirmed by Joyce to Herbert Gorman, when another boy broke Stephen's glasses and Father Dolan pandied the victim on the mistaken premise that he had broken the glasses himself to avoid study. Father Dolan was in real life Father James Daly, the efficient prefect of studies at Clongowes for thirty years, and a martinet. Joyce was to speak of him later to Gorman as 'low-bred.' He was not then the white-haired old man described in the novel, but a dark-haired tyrant of about forty. On this occasion Joyce bravely protested to the rector, Father Conmee, and was sustained by him. Probably at this time the other boys began to respect him; such a development is suggested, a little obscurely, in A Portrait of the Artist as a Young Man, and is borne out by accounts of Joyce's life at the school by contemporaries (Ellmann, p.27).

The religious formation he received in the Jesuit schools also shaped Joyce, giving him first a faith to believe in and then a weight to rebel against. Like Stephen, he was the son of a religious mother and was for a time devoutly religious, and then found that other attractions prevailed. Like Stephen, Joyce had early experiences with prostitutes during his teenage years. By the age of fourteen he had begun his sexual life in Dublin brothels, and though he was temporarily overwhelmed with remorse after a religious retreat held at his Catholic school (just like Stephen), he soon saw that he could not lead the life of virtuous obedience demanded of a priest. Instead, he exchanged religious devotion for devotion to writing. Joyce, like Stephen, left Ireland to pursue the life of a poet and writer. Considering these similarities in both Stephen's and Joyce's careers, one could agree with Margaret Norris' assertion in Joyce's Web: The Social Unraveling of Modernism that "A Portrait is both the author's autobiographical fiction and the autobiography of the fictional character. It provides the portrait of both artists" (p.51).

\section{Catholic Values: Sin and Punishment, the Sacramental Economy.}

Sin and punishment go together. Trese (1998) explains that God is merciful and equally just and so cannot be indifferent to moral evil. If there was no penalty attached to sin, then good and evil would stand side by side as seeming equals; justice would be an empty word (p.384). According to Catholic teaching, God's punishment has the salvation of the wrong- doer in view. It is meant to help him to be vigilant in order not to lose his soul. The Catechism of the Catholic Church Compendium explains that the sacraments, instituted by Christ and entrusted to the Church, are efficacious signs of grace perceptible to the senses. Through them divine life is bestowed upon the faithful. There are seven sacraments, namely: Baptism, Confirmation, Holy Eucharist, Penance, Anointing of the Sick, Holy Orders and Matrimony (No. 224)

Nkengasong and Joyce echo these Catholic norms or values in their novels. In God Was African, Kendem reports that his mother was a devoted convert of the Roman Catholic Church and had introduced him in the faith from birth (19). He received the sacrament of baptism a few days after his birth (p.20) which tie in with the Catholic doctrine on infant baptism (The Catechism of the Catholic Church No. 258). Kendem says his faith in Christianity never wavered and by the time he reached class five, he became a mass servant. He helped in cleaning the sacristy before Father Tom arrived Lewoh mission station from Mbeta once every two months. Before his arrival every Christian had to prepare himself or herself for Holy Communion which is one of the seven sacraments of the Church. He goes on to say that: "Preparing oneself meant attending doctrines regularly, participating in the cleaning of the church and its premises, washing the priest's toilet, attending choir practice, and sometimes cleaning the cemetery" (21). Father Tom usually arrived on Saturday afternoon. He spent the rest of the day 
hearing confession, another sacrament of the Church. This means that Christians confess their sins in order to prepare themselves to receive Holy Communion on Sunday.

It is Catholic doctrine that anyone who receives Communion in a state of sin was condemning his soul to eternal damnation if the person dies without repentance. Kendem feels guilty he has sinned by questioning interiorly if his illiterate folk understood latin which was the language of mass and why Father Tom hated Nweh songs because he considered them pagan. This was one of the mistakes the whites who bought Christianity to Africa made by believing that anything African was paganic and evil. This necessitates Kendem to feel guilty over what is neither evil nor sinful. Kendem thinks he has committed a mortal or grave sin by taking part in his ancestral ceremonies: "I was committing a mortal sin. I was violating the ways of God in heaven above by thinking about heathen worship which Father Tom said was the work of satan"(27). It should be noted that Christian belief is sky oriented while African traditional belief is earth oriented. Kendem feels guilty for sharing his traditional religious belief that only wizards and evil spirits visit the sky while Christians believe it is God's abode (27). Consequently, he makes up his mind to go to confession the next time Father Tom comes to cleanse his soul before receiving Holy Communion. He indeed goes for confession as he states: "When he was ready, I met him at the altar, knelt in front of him, crossed myself and confessed my sins then said the confession payer and he blessed me" (27).

Nkengasong also projects matrimony, another sacrament of the Catholic Church. The Church preaches monogamy while traditional religion upholds polygamy for various reasons. Kendem's mother being the first of his father's five wives got married with his father in church when she embraces the Catholic faith. Kendem reports:

She was an early Christian of the Roman Catholic Church when it was first established in Lewoh country... The church preached one man one wife. As my mother told me, the church accepted her because she was the first woman from a polygamous home to become a Christian and the deed of conversion was accepted by the priest as a way of making my father abandon his four other wives and accompany my mother to church. She made mention of a chief who had abandoned his twelve wives after baptism and got married to a woman who also accepted baptism (p.20).

The Roman Catholic Church was a potent force in Joyce's native Ireland throughout and beyond the nineteenth century, not only in terms of the doctrinal and spiritual guidance it provided but also because of the influence it exerted upon the cultural and political life of the country. Despite Joyce's rejection of the Church's practices in Ireland, Catholicism exerts an immense influence on his artistic life. It is not surprising though, because he received a pure Catholic upbringing since his childhood years. Joyce remained with the Jesuits for about fifteen years. He entered the Jesuit institution at the age of six and a half and left the latter in 1898 at the age of sixteen. He was first educated at the Jesuit College Clongowes Wood, a prestigious Jesuit school in County Kildare. After only two years because of financial constraints he and his brother were enrolled briefly at the Christian Brothers and then as day students at the Jesuit school, Belvedere College. Joyce culminated his studies at the Catholic University of Dublin (Fargnoli and Gillespie, p. 2). The positive impact of religion on Joyce's upbringing is echoed in the third chapter of $A$ Portrait of the Artist as a Young Man where Stephen does not express disbelief or lack of faith in God. On the contrary he is familiar with the deep tenets of Catholicism

. During his schooling at Belvedere, Stephen is known for his piety and is chosen by his peers to be the prefect of the sodality of the Blessed Virgin Mary. Consequently, Stephen draws the attention of the director, who suggests that he consider a vocation to the priesthood. In real life James Joyce had a parallel experience as reported by Ellmann (1983) in his biography: "The last appealing voice was that of the director of studies who suggested to Joyce, in a solemn interview when, according to Stanislaus Joyce, the boy was sixteen, that he consider becoming a priest" (p.55). In the last chapter, Cranly, after a long discussion, concludes that Stephen's mind is supersaturated by the religion he is claiming to reject. Cranly asked Stephen if he believed in the Eucharist to which he answered he "neither believe nor disbelieve". The Eucharist is another name for the sacrament of Holy Communion. Through his discussion with Stephen, it becomes clear to Cranly that Stephen's mind is supersaturated with the tenets of Catholicism. When Stephen has finished expounding his aesthetic theory, his friend Lynch comments that it has the true scholastic stink (p.245). Joyce's conception of himself and his mission as an artist uses the language of priesthood. The novel is full of language strongly linked to religious doctrines and beliefs such as priest, soul, body and sin. Mostly crucial to Joyce's studies when it comes to religion is the influence Saint Thomas Aquinas had on him. Joyce left Ireland loaded with the knowledge he had acquired from the Jesuits. Thus when he said "This race and this country and this life produced me... I shall express myself as I am" (p.202), Joyce is in fact acknowledging his indebtedness to Irish culture and religion in particular which had shaped his psyche. As a result of his Catholic upbringing, Joyce explores the belief in the sacrament of Holy Communion in the incident in which the five boys in Stephen's school steal altar wine from the sacristy. The sacristy is a holy place. The students' theft is not only a crime but is a sin of sacrilege as well. In Catholic doctrine consecrated bread and wine by the priest become the real body and blood of Jesus Christ and is reverently adored. As such 
the bread and wine kept for consecration should be guarded with respect. Only with the eyes of faith can one believe in this sacrament.

Nationality, language, religion, the nets which enclose Stephen as a child and adolescent, are in fact inextricably intertwined, with religion as the central strand. Religion permeates his home life, his induction into the adult world of Irish politics, his school life, his expectations for the future, much of the literature he reads, and even the language with which he expresses himself. An understanding of the interrelationships between Catholicism, family life, guilt, fear and punishment is indoctrinated into Stephen from an early age. As an infant, he says that he will marry Eileen, a protestant. The reaction is unfavourable. He is rebuked by his mother and Dante joins in the reprimand because Catholics and Protestant disagree. Joyce in real life went through this same experience of prohibition from associating with Protestants as Ellmann writes in his biography:

By age and temperament Joyce became the ringleader in the children's games. Along the street, at 4 Martello Terrace...lived a chemist named James Vance with his family, and although the Vances were Protestant, the families were quickly drawn together. Vance's bass voice boomed against John Joyce's light tenor in 'Come-all-ye's.' The Vances' eldest child, four months younger than James, was a pretty girl named Eileen, and the two fathers often spoke half-seriously of uniting their first-born. Dante Conway warned James that if he played with Eileen he would certainly go to hell, and he duly informed Eileen of his destination but did not cease to merit it (p.28).

Dante was a very fervent Catholic but fanatic to believe one can go to hell just by interacting with Protestants. By hiding under a table, the child manifests his awareness of culpability, even if he does not yet understand his crime. Similarly, acceptance of the intellectual authority of the Church has been instilled into the child at a very young age. Stephen has learned that Dante is a clever and well- read woman, but at the same time he believes that "Father Arnall knew more than Dante because he was a priest" (p.6).

As proof that his religious upbringing is not in vain and that he is still spiritually conscious in spite of his sins of lust and pride, Stephen feels morally uncomfortable and guilty, because he considers his act of fornication a big sin in relation to religion. Fornication is a grave sin against the sixth commandment handed by God to Moses on Mt Sinai. "He had sinned mortally not once but many times and he knew that, while he stood in danger of eternal damnation for the first sin alone, by every succeeding sin he multiplied his guilt and his punishment" (96). When he attends a school retreat organized in honor of Saint Francis Xavier, the priest's hell-fire sermons move him to anguished self-disgust and terrified remorse just like Joyce in real life as reported in by Ellmann:

he was readier than he knew for the retreat which began on November 30, 1896. In charge of the retreat was Father James A. Cullen, and his sermons, delivered, as was customary, according to the prescription of St. Ignatius Loyola's Spiritual Exercises, elicited a more than customary number of twinges from hell-fire. All Joyce's mounting scruples against his own conduct found a fierce justification. He saw himself as a beast, eating like a beast, lusting like a beast, dying like a beast, and dreamed of a pure love for a virgin heart (p.48).

Joyce like his mouthpiece Stephen does not confess in the school chapel because of shame and pride: "to abase himself before Father Henry was too much to bear". After his confession, Joyce like Stephen cultivated a life of prayer, mortification and virtue. Nevertheless, this is to be shortlived as he will soon feel that it is inhibiting to his individual freedom to indulge his whims and caprice. Chapter three focuses almost exclusively on giving an account of the religious retreat that the boys at Belvedere have to make, and it specifically foregrounds the sermons preached by the retreat master, Father Arnall. Although the retreat receives a rather melodramatic representation, heightened by the selective attentiveness of Stephen's overactive imagination, the liturgy itself was a long-established practice and, as Joyce would have known, one held in particular esteem by the Jesuits. (The Society of Jesus was the first religious order that made the retreat obligatory for its members.) The format of the retreat described in this chapter follows the standard approach prescribed at that time by the Church. It has the retreat master leading the boys toward personal assessments through a series of meditations on death, the Last Judgment, Hell, Purgatory, and Heaven. Despite the actual breadth of the retreat format, in passage after passage, Stephen dwells exclusively upon the consequences of his mortal sins, and this state of mind brings him to repentance based on fear of punishment as a consequence. Fargnoli and Gillespie (1995) report how a Joyce scholar, Professor James R. Thrane, has shown that Joyce derived much of the text of Father Arnall's sermons from a devotional work entitled Hell Opened to Christians, To Caution Them from Entering into It written in 1688 by an Italian Jesuit, Father Giovanni Pietro Pinamonti. An English version of the work was published in Dublin in 1868, and it may very well have served as the basis for similar sermons that the young Joyce heard at Belvedere during retreats that he made (p.142). 
However, Stephen like Joyce comes to realize that his future cannot be in subjection to an ordered system as in the Church. In his view, the Irish Catholic Church is provincial, narrow and hostile to what he considers important: freedom and justice. On the contrary the Church promotes freedom and responsibility in spite of Joyce's negative view. Gradually, therefore, his soul becomes unable to harbor religious principles or views for any time though he forces his lips to utter them with conviction. It gives rise to a view of crisis in Stephen, since he thinks that religious rules both confine individuals and cripple their feelings. Hence a sense of sickness and unrest begins again to irradiate his being and consciousness: Stephen gathers his impressions of religion and priesthood as well as of the division which religion and politics have brought about in the consciousness of Irish people. Through his representation of Stephen, Joyce shows us his own break up with the Catholic Church, but he also encounters the loss of a world of public values. When Stephen gains psychologically more freedom and becomes bolder in his mind, he turns round on politics and religion to question the status quo and its social code that control him.

The Irish Church was sick with clericalism, a disordered exaltation of the status of priests. According to Father Power (2016), "The clericalist distortion of Christianity" led to "religious aristocratism," much to the detriment of lay spirituality. This leads Father Power to make a crucial distinction between anti-Catholicism and anticlericalism. Joyce, he says, "was deeply anticlerical because he disliked the institutional form taken by Catholicism in the Ireland of his youth." Yet "he remained haunted by the essences of the religion he only seemed to flout." In leaving Ireland, Joyce exiled himself from his native country - yet went on to write about nothing but Dublin. He rejected the Irish Church and yet he was able to express himself only in "Catholic categories." Joyce's brother Stanislaus, an atheist, acknowledged this, saying that James, to the end, "considered Catholic philosophy to be the most coherent attempt to establish ... intellectual and material stability" (AngelusNews.com). In a surprising turn, Father Power identifies a kindred spirit for Joyce in Saint Josemaría Escrivá, the founder of Opus dei (www.opusdei.org). This Spanish priest was roughly Joyce's contemporary, and he shared Joyce's horror of clericalism as well as his desire to epiphanize the faith in material ways and in ordinary life. In synthesizing the thought of these two men, Father Power concludes his book James Joyce's Catholic Categories by proposing "a Christian aesthetic of the ordinary." The stunning example of this comes in a climactic scene in Joyce's novel when Stephen is moved to ecstasy by the sight of a young woman playing at the beach: "He was alone. He was unheeded, happy and near to the wild heart of life. ... Heavenly God! cried Stephen's soul, in an outburst of profane joy." For Stephen, as for St. Josemaría, there is no inherent contradiction between the sacred ("Heavenly God!") and such pure and " joy" in the light of the gospel experienced in the world.

\section{Conflict between Roman Catholicism and the people's culture or traditional Religion}

In Ireland, Roman Catholicism had long been a focus of nationalist resistance against English colonialism such that "Irishness" had come to be seen by many as synonymous with Catholicism. However, Ellmann reports in Joyce's biography how the Catholic Church joined forces with others to overthrow Parnell who though he fought for Irish independence was guilty of the sin of the flesh:

When James came home during these Clongowes years, from 1888 to 1891, his father and John Kelly had no subject for talk but Parnell. Ireland's 'uncrowned king' was now on his way to becoming her tragic hero... The vindicated Parnell now reached the height of his reputation, and his country united behind him. But the day before Christmas of that year, 1889, Captain William Henry O'Shea filed a petition for divorce from his wife Kitty on the ground of her adultery with Parnell... Within three weeks of the divorce the party was split in Committee Room 15, and within a year Parnell was dead. Parnell's defeat was always spoken of by his adherents as his betrayal,... and the word betrayal became a central one in Joyce's view of his countrymen (p.2).

Although Joyce and Parnell's adherents consider his defeat as an act of betrayal, objectively it is not. The church's role is to uphold upright moral behaviour and not to condone with evil. Though Joyce renounced Catholicism because of the interference of the Church in Irish politics and its attitude to sexual morality, he could not completely detach himself from it. Ellmann (1984) cites Joyce as saying: "I left the Catholic Church, hating it most fervently. I found it impossible for me to remain in it on account of the impulses of my nature" (1). Consequently, it is because of Joyce's refusal to self-mastery as commended by the church that he renounced the faith. His attitude towards religion was ambivalent. In this light therefore, Lewis Pericles in "Modernism and Religion", comments about the modernist's ambivalent attitude towards religion by writing that:

The modernists were not the devout secularists that many critics portray; instead, they were seeking through their formal experiments to offer new accounts of the sacred for an age of continued religious crisis. Joyce's Stephen Dedalus may shun the Catholic Church and Woolf's Mrs. Ramsay chastise herself for thinking, in an unguarded 
moment, "we are in the hands of the Lord" (To the Lighthouse 101). Yet, their creators continued to search for an adequate account of religious experience, a kind of essence of religion without God or Church, and this search contributed to the development of literary modernism (p.4).

To search for "a kind of essence of religion without God or Church" by literary modernists is futile because without God man can do nothing and is doomed to fail. Man is a religious being and can never totally repudiate religion and God because it is imprinted in the conscience. Joyce believes that the individuality of the Irish people has been subsumed in a religion whose moral, political and cultural influence denied them any opportunity to make choices for themselves. He feels that the attitude of the mass of Irishmen towards their religion was in the words of Stephen Dedalus, that of "a dull- witted loyal serf" (p.139).

The incident of the quarrel about religion and politics which leaves young Stephen confused is a real life experience of Joyce which project how his consciousness was greatly affected. The image of home as a haven of security and certainty, which sustains Stephen during the lonely torment of his early schooldays at Clongowes, is shattered by the argument over the role played by the Catholic clergy in the downfall of Parnell, which ruins his first Christmas dinner with the adults. What should have been a happy milestone in Stephen's development leaves him "terror- stricken" and confused about the relationship between politics and religion (29). Ellmann writes about this incident in Joyce's biography:

Parnell's death made matters worse by overweighting his tragedy with martyrdom. Joyce has described the Christmas dinner in 1891, when his father and John Kelly raged and wept over Parnell's betrayal and death, and Dante Conway, full of venomous piety, left the table. The argument was so acrimonious that the Vances heard it along the street. Probably the evidence of Ulysses can be trusted that Mrs. Conway left the house for good four days later. A more important after- effect was that for the Joyces, father and son, all was bathos now in Ireland; no politician and no politics were worth working for (p.34).

The attitude of the Irish towards the Church is seen in the contrast between Dante's "venomous piety" and the tears shed by John Joyce and his friend John Kelly who consider the Church a traitor in the Parnell case. The consequent effect of the quarrel is that "for the Joyces, father and son, all was bathos now in Ireland". In his boyhood, therefore, Stephen like Joyce sees his elders as bitterly divided in their consciousness in terms of religion and politics. As Stephen matures he gains a clearer understanding of the fate of Parnell, and others like him, who devoted their lives to their cause only to be denounced with the complicity of the Catholic clergy. Stephen, who is himself named after a martyr, begins to identify to some extent with Parnell. Recalling the dream of dying which he experienced during his confinement in the infirmary at Clongowes, and which coincided with the death of Parnell, Stephen reflects: "But he had not died then. Parnell had died" (p.24). The undermining of Stephen's confidence in the priesthood, which begins at the Christmas dinner table, is exacerbated by the cruel and arbitrary punishment he receives at the hands of Father Dolan when he accidentally breaks his glasses. This is a real life experience which pained and traumatized Joyce. Ellmann records this incident in Joyce's biography:

The worst event of the early months was the incident described in A Portrait and confirmed by Joyce to Herbert Gorman, when another boy broke 'Stephen's' glasses and 'Father Dolan' pandied the victim on the mistaken premise that he had broken the glasses himself to avoid study. Father Dolan was in real life Father James Daly, the efficient prefect of studies at Clongowes for thirty years, and a martinet. Joyce was to speak of him later to Gorman as 'lowbred (p. 28)

Stephen like Joyce comes to realize that his future cannot be in subjection to an ordered system as in the Church. In his view, the Irish Catholic Church is provincial, narrow and hostile to what he considers important: freedom and justice. On the contrary the Church promotes freedom and responsibility in spite of Joyce's negative view. Gradually, therefore, his soul becomes unable to harbor religious principles or views for any time though he forces his lips to utter them with conviction. It gives rise to a view of crisis in Stephen, since he thinks that religious rules both confine individuals and cripple their feelings. Hence a sense of sickness and unrest begins again to irradiate his being and consciousness: Stephen gathers his impressions of religion and priesthood as well as of the division which religion and politics have brought about in the consciousness of Irish people.

Before Christianity came to Africa, the people had their traditional religious beliefs and practices which influenced their thought processes and worldview. Consequently, there was bound to be a conflict between Christianity and traditional religion and culture of the people. Nkengasong echoes this conflict in God Was African. In chapter two of the novel, as Kendem sits drinking palm wine with the villagers in a bar, the discussion is about the conflict between the Catholic Church and the traditional religion of the people concerning the burial of Fuo Beyano. Commenting about it, one of the people says: "This matter has teeth. It will split Lewoh country if not handled in both hands" (p.8). Another person says, "But the Church 
should know that it did not travel from wherever it came and found a vacuum in Lewoh country" (p.8). Yet another villager states, "I blame the chief. He did not initiate his children well. The children are now insisting on a Christian burial for their father. But some of the fathers of the land do not think that this is the right thing to do to a departed chief who was one of the custodians of our culture and who knew that he was to travel to the land of his ancestors and then return $s$ tradition demands" (p.8). With the coming of Christianity to Africa, some converts including the educated were made to believe their traditional religion was primitive and served no purpose. Kendem adopts this attitude in the novel when his mother asks him to visit the ancestral shrine to honour and greet his late father. Kendem declares "I had believed that the shine no longer had a place in modern life. And as I went to college and and continued the academic trip to the university I didn't think I should be easily steered in to primitive cultures" (p.16).

Other Africans embraced and lived both the Catholic and traditional religions. This is the case of Kendem's mother who introduced him to the faith. She never lost grip of the spiritual essence of her ancestors. "The two faiths resided in her soul and each had occasion for expression, either during her normal Sunday morning worship and events organized by the church or during a village cultural activity which required the performance of rites and rituals" (p.19). Christianity and the Catholic church in particular preaches monogamy while traditional religion upholds polygamy. This is why those polygamists who embraced Christianity had to renounce their many wives and got married in Church with the first wife as is the case with Kendem's mother who was the first of five wives. But his father was a bad convert who resisted the teachings of the Catholic Church. He went to church once and swore he would never go there again. He said the men and women who went to church gossiped about their spouses to the white priest. He questioned why the priest was not married. In the Catholic church priests don't marry as they imitate Jesus who was not married.

To Kendem's father, priests were the satans, wizards and perpetators of broken homes and problems of inheritance. "And so my father turned towards his ancestors. He had built the shrine in the backyard of the main house of the compound in which he displayed relics of his ancestors and offered sacrifices to them at different times of the year" (p.29). As Kendem grew up and went to the Roman Catholic Mission School to learn Christian education, his father initiated him into ancestral beliefs and rituals in the shrine. Nkengasong through Bombabili condemns the hypocrisy of the white Christians who preach but don't practice what the teach. The Church outrightly condemns homosexuality as evil and abominable but some white Chistians still indulge in it. Kendem narrates his gandfather's experience who fought in World War II how soldiers pratised homosexuality: "He told us he see thing with his own eye and wanda whether those people worship the same God that thy bring to Africa? He said man soldier was doing thing with man soldier" (41). Whites also engagaed in cannibalism which is condemned by Christianity: 'He said he saw man kill man and eat him raw without cooking..." (p.41). This is in glaring contrast to the civilization the whites claimed to bring to Africa. It is easier to preach than to practice.

Kendem whose real name is Nkue- ndem which means God's message, wondered who God was. He questioned if He was the one his father worshipped or the one his mother worshipped when he was born. As Kendem goes to a Catholic church on Sunday in America, he is shocked to see that very few people, mostly the old, attend mass unlike in Cameroon where the church is always packed full. This would only emphasise in his mind that people don't live what they preach and consequently his Christian faith is challenged. In a conversation between Kendem and Bombabili, the former asks if the chief and notables still offer sacrifices to their gods and ancestors to which the latter replies that they do so just occasionally. Bombabili then complains bitterly in broken English how this is the consequence of Christianity which asked the people to destroy their religious objects as they were considered satanic and barbaric:

And you people force us to put our jujus in the fire and burn it. Is only after that we knows that God was African. Let me tell you again to and fro that God was African. And yet you pipu says our God was satanical and that our culture was barbarical. And yet we didn't hamme our God on the cross. We didn't beat him to dead. You see, we was not barbarical to our God. We show love to our God. That why we offer them sacrifice. We slaughter goat and give them to eat and we give them raffia wine to dring (p.129).

Bombabili goes on to say that they have many gods, one big God called Fuondem and many small gods who inhabit the forest, hill, rock, valley and the waterfall in Lebialem (p.129). The belief in many Gods clashes with the Christian belief in one God. Tension increases between the children of the late chief and the chief and elders as each holds to their own position about the burial- Christian and traditional respectively. Finally, the chief who is the custodian of culture declares traditional rites have to be performed on the late chief and he can then be taken to church for a requiem mass. During the traditional rites, Atemangwat the paramount chief chooses the successor of the late chief among his many children. Through the successor, it is believed the late chief has returned, "The chief of Beyano who had disappeared had now retuned. Shortly 
afterwards, the whole cabinet rose, led by the new chief to pay his allegiance to Nyamtemeh, to Atemangwat, the paramount ruler of the land" (p.263-4).

The celebration of the departure and return of Fuo Beyano is to start the following day after a requiem mass. During the mass, the priest in his homily preached about who a true Christian was. He quoted the late chief, Thompson Tazi- Nyang, as an example of a true Christian who though a chief, was not involved with heathen cults but had accepted Christ as his savior (p.271). He went on to say Christianity was the religion that purified the soul and bought it closer to God, provided room for the understanding of God's mission on earth and for which he sent his son Jesus Christ to spread the gospel of faith. "The mission of the Catholic Church the world over and which had its roots in Rome was to fulfil this mission" (p.271). In a stream of consciousness, Kendem ponders about the two religions and concludes: "I knew one fact and believed fervently in it- that God, the creator of life, exists" (p. 272). Bishop Andrew Nkea in a reply to a question about the attitude of Africans, in particular the people of Lebialem, towards Christianity, said that the Christian in the face of traditional religion must know that they cannot be like the traditional juju with two faces, the Christian face and the non- Christian face. They must also remember that they must be authentically Christian and still remain authentically Africans. This means that the African Christian can truly live within his culture as an African, rising above the negative values of tradition that Christ has purified with the values of the gospel (Chiara, 2016).

\section{Conclusion}

The objective of this paper was to demonstrate that although Joyce is European and his work traces the development of a potential artist in a colonised Ireland and Nkengasong is African and projects the experiences of a scholar in a postcolonial Cameroon, both converge in the exploration and critique of the doctrine and teachings of the Roman Catholic Church whose mission is universal. This paper demonstrates that Joyce and Nkengasong both bridge the dichotomy between art and life through the inclusion of real life experiences in their works. The experiences of their protagonists as Roman Catholic Christians echo their real life experiences. The writer becomes both the subject and creator. The Roman Catholic Church is portrayed as very powerful and influential in the life of the people wherever its Christian faithful are found. It clashes with the way of life of the various peoples but its doctrine and teachings serve as the light. Though Joyce and Nkengasong are not comfortable with its strict rules, they nevertheless mirror it in their works because its influence on them from childhood is too significant. Their critique is for reformation and not rejection. Joyce is Irish while Nkengasong is Cameroonian hence there is bound to be differences. Nkengasong uses both English, broken English and the dialect of his people to reflect his milieu while Joyce uses English and baby language to suit the age of his protagonist and his Irish milieu. The conflict in colonized Ireland is between the Catholic Church and politics which in turn affects family and social life as evident in the quarrel at the Christmas dinner which is an important religious event. In postcolonial Cameroon, the conflict is between the Catholic Church and the people's traditional religion which in turn affects family life and that of the entire village as evident in the conflict about the burial of the chief. Both Nkengasong and Joyce may have realized that if God is rejected, man and society inevitably become dehumanized. God's laws were established for the protection and preservation of human nature by means of which the individual is to find his personal dignity and reach the goal for which he was created. The teachings and doctrine of the Roman Catholic Church are universal but there is inculturation in respect of the positive values of the people's culture.

This study had the problem of funding as limitation since it was self- funded from my limited financial means as well as the problem of electricity going on and off which made it difficult to work within the time frame and to access the internet with ease. Having access to critical works on Nkengasong's God Was African was problematic as not many critics have appraised it since it is relatively a recent book. As suggestion for further research, an article could focus on the comparative analysis of socio- political consciousness in James Joyce's A Portrait of the Artist as a Young Man and Nkemngong Nkengasong's God was African to show how colonization and the political circumstances in which they lived impinged on their thoughts and feelings and influenced their works to be autobiographical novels. 


\section{References}

[1] Abrams, M. H. (1999). A Glossary of Literary Terms. New York: Heinle \& Heinle.

[2] Ambanasom, A. S. (2009). The Cameroon Novel of English Expression: An Introduction. Langaa Research \& Publishing CIG, Mankon, Bamenda.

[3] Betoto, J. E. (2012). Missionary activity in Bakunduland, Cameroon, 1873-1960: An historical appraisal. Global Advanced Research Journal of history, political science and International Relations, 1(2), 48-55

[4] Blamires, H. Critical Notes on A Portrait of the Artist as a Young Man by James Joyce. London: Longman Group Ltd, 1990.

[5] Cox, J. N. and Reynolds, L. J. (1993). New Historical Literary Study, Princeton: Princeton University Press.

[6] Ellmann, Richard. (1983). James Joyce. Revised Edition. Oxford: Oxford University Press.

[7] _ _ _ - (1975). ed. Selected Letters of James Joyce. London: Faber and Faber.

[8] Ethnologue (2016). Cameroon languages. Retrieved from https://www.ethnologue.com/language/nwe/map

[9] Fargnoli, N. A. And Michael. P., eds. (1995). James Joyce A- Z: The Essential Reference to His Life and Writings. Oxford: Oxford University Press.

[10] Favotti, C. (2016). Cameroon: Christianity and the Bangwa Culture. Interview with Mgr. Andrew Nkea. Retrieved September 19, 2020, from <www.focolare.com>

[11] Gibson, A. Time Drops in Decay: A Portrait of the Artist in History (ii), Chapter 2. James Joyce Quarterly, Volume 44, No. 4, Summer 2007. 697-716.

[12] Joyce, J. (1964). A Portrait of the Artist as a Young Man. London: Grafton Books.

[13] Joyce, S. (1958). My Brother's Keeper: James Joyce's Early Years. ed. Richard Ellmann, New York: Viking.

[14] Mbiti, J. S. (1970). African religions and philosophy. Garden City, NY: Anchor.

[15] Njoh, A. J. \& Akiwumi, F. A. (2012). The impact of religion on women empowerment as a millennium development goal in Africa. Social Indicators Research, 107(1), 1-18.

[16] Labang, O. C. (2014). Riot in the Mind: A Critical Study of John Nkemngong Nkengasong. Miraclaire Academic Publishing, pp 146- 169

[17] Mbangchia, Chester. (2018). God Was African by Nkemngong Nkengasong: A Review. Retrieved September 16, 2020 from <https: //books. Google,cm/books/ God was African.html>

[18] Ndemanu, M. T. (2018). Traditional African Religions and Their Influences on the Worldviews of Bangwa People of Cameroon: Expanding the Cultural Horizons of Study Abroad Students and Professionals. Frontiers: The Interdisciplinary Journal of Study Abroad, $30(1), 70-84$.

[19] Nkengasong, N. (2014). God Was African. Langaa Research \& Publishing CIG, Mankon, Bamenda.

[20] Segall, J . (1993). Joyce in America: Cultural Politics and the Trials of "Ulysses."Berkeley: University of California Press.

[21] Teke, C. N. Postcolonial Innovative Creativity and Transformational Poetics: An Interview with Nkemngong Nkengasong. 1-12. 28 March 2016. <https://www.researchgate.net/publication/272138493>.

[22] Power, Father Colum. (2016). James Joyce's Catholic Categories. Wiseblood Originals. Retrieved September 18, 2020, from AngelsNews.com

[23] The Catechism of the Catholic Church Compendium. (2006). Paulines Publications Africa.

[24] Trese, L. J. (1998). The Faith Explained. Sinag- Tala Publishers, INC. Manila.

[25] Varughese, E. D. (2012). Beyond the Postcolonial World: World Englishes Literature. Palgrave Macmillan.

[26] Welan, K. (2002). The Memories of The Dead. The Yale Journal of Criticism, 15(1), The Yale University and The Johns Hopkins University Press. 59-97. 